\title{
Chemical Ecology of Astigmatid Mites. LXXI. Neryl Formate ( $Z$ )- 3,7-Dimethyl-2,6-octadienyl Formate as The Alarm Pheromone of Tyroborus lini Oudemans 1924, and Its Recovery after Forced Discharge
}

\author{
Akihiro TOMITA, Nobuhiro SHIMIZU, Naoki MORI, Ritsuo NISHIDA, Hiroshi NAKAO* \\ and Yasumasa KUWAHARA \\ Laboratory of Chemical Ecology, Division of Applied Life Sciences, Kyoto University, \\ Sakyo-ku, Kyoto 606-8502, Japan \\ *Kamikawa Agricultural Experiment Station, minami 1-5, Pippu-cho, Kamikawa-gun, \\ Hokkaido 078-0311, Japan
}

(Received 1 November 2002; Accepted 27 April 2003)

\begin{abstract}
The presence of the alarm pheromone was demonstrated in the hexane extract of an acarid mite Tyroborus lini Oudemans 1924. The active fraction derived from an $\mathrm{SiO}_{2}$ column chromatography of the mite extract was identified as neryl formate, (Z)-3,7-dimethyl-2,6-octadienyl formate by GC/MS and GC analysis. The synthesized neryl formate was shown to be active at $0.05-1 \mathrm{ng}$ dose. Males contained $0.08 \mathrm{ng}$ of the compound on average, and females $0.16 \mathrm{ng}$ on average. The alarm pheromone was a component present in the opisthonotal gland. Once totally discharged from the gland upon disturbance, it took seven days before the pheromone content reached to its original level in the gland, whereas other compounds recovered within $60 \mathrm{hrs}$. The reason remains obscure at present.
\end{abstract}

Key words: Tyroborus lini, alarm pheromone, neryl formate, (Z)-3,7-dimethyl-2,6-octadienyl formate, Astigmatid mite

\section{INTRODUCTION}

Tyroborus lini Oudemans 1924 (Astigmata: Acaridae) is one of the potential stored product pests like Tyrophagus mites and known as one of the 10 species achieving the greatest density in poultry droppings in the pits or battery residues of broiler houses (Brady, 1970). The genus Tyroborus looks similar to Tyrophagus morphologically and has once grouped as congeneric (Brady, 1970).

T. putrescentiae, one of the most frequently encountering species belonging to the genus Tyrophagus, not only has been found on various decaying crops in the field and organic matters in soil but also has been detected as a pantry pest attacking stored products (Nakao, 1991). T. similis and T. perniciosus are noxious pests for vegetable such as spinach, melon and cucumber. T. neiswanderi is injurious to orchid flower and cucumber in the greenhouse (Nakao and Kurosa, 1988).

Astigmatid mites possess a pair of secretory gland in the opisthosoma, which are called opisthonotal glands or oil glands. Many volatile compounds such as monoterpenes, aromatics

*To whom correspondence should be addressed. Tel: +81-75-753-6309, Fax: +81-75-753-6312, E-mail: kuwa34@kais.kyoto-u.ac.jp 
and hydrocarbons, are identified as components of the gland exudates. Parts of compounds function as alarm, aggregation and sex pheromones (Kuwahara, 1991, 1999).

Tyrophagus mites are known to possess each alarm pheromones as follows; neryl formate in T. putrescentiae (Kuwahara et al., 1975), isopiperitenone [3-methyl-6-(S)-isopropenyl-2cyclohexene-1-one] in T. similis (Kuwahara et al., 1987) and a mixture of alkenes in $T$. neiswanderi (Kuwahara et al., 1989), $\beta$-acaridial [2(E)-(4-methyl-3-pentenylidene)-butanedial] in T. longior (Noguchi et al., 1998), and 2-hydroxy-6-methylbenzaldehyde in T. perniciosus (Leal et al., 1988).

A strain of T. lini was successfully cultured in our laboratory to study its chemical ecology, and the possible presence of an alarm pheromone was examined. The active principle(s) of the alarm pheromone was identified, and its recovery rate in the gland's reservoir with other components was examined after total discharge upon artificial disturbance.

\section{MATERIALS AND METHODS}

Mites. The mite Tyroborus lini was collected from organic soil adjacent to a poultry pen in Kagoshima Prefecture. The species was maintained in a plastic Petri dish $(90 \mathrm{~mm}$ in diameter, $20 \mathrm{~mm}$ in height) at $25^{\circ} \mathrm{C}$ by feeding dry yeast. The Petri dishes was kept in a ziplocked polyethylene bag to maintain relative humidity around $80 \%$.

Bioassay. The assay plate was prepared by turning upside down a cover part of the Petri dish of a stock culture with an appropriate population, on which appropriate number of escaped mites from the culture medium had been placed naturally. The plate was then placed on a sheet of paper with many printed circles ( $8 \mathrm{~mm}$ in diameter). After 5 minutes of conditioning, during which most of mites became motionless, an adult mite arbitrarily selected was placed at the center of a circle by shifting the paper underneath. A piece of filter paper $(4 \mathrm{~mm} \times 2 \mathrm{~mm})$ which had been previously impregnated with a candidate material in $1 \mu \mathrm{l}$ aliquot, was introduced beside the tested mite within the circle after the solvent being evaporated by keeping the paper in a air for a few minutes. The time as second necessary for the mite to move out from the set circle was measured after introduction of the filter paper with 20 times repetitions, and the result was compared with that of the solvent control.

Analysis method. Gas-liquid chromatography (GC) was performed on an HP-5890 Series 2 Plus Gas Chromatograph equipped with FID. An HP-1 capillary column $(0.2 \mathrm{~mm} \times 25 \mathrm{~m}$, $0.33 \mu \mathrm{m}$ in film thickness) was used at a temperature programmed from $60^{\circ} \mathrm{C}$ to $290^{\circ} \mathrm{C}$ at $10^{\circ} \mathrm{C} / \mathrm{min}$ with an initial $2 \mathrm{~min}$ hold. The sample was analyzed as a split-less mode using $\mathrm{He}$ as a carrier gas at $1.23 \mathrm{ml} / \mathrm{min}$ flow rate. An HP3396 Series 2 Integrator processed the chromatogram.

Gas chromatography coupled with mass-spectrometry (GC/MS) was executed by an HP$5989 \mathrm{~B} \mathrm{GC/MS}$ spectrometer with a low resolution mode at $70 \mathrm{eV}$ and the split-less mode. An HP-5 (0.32 mm $\times 30 \mathrm{~m}, 0.33 \mathrm{~mm}$ in film thickness) capillary column was used under the same conditions as those mentioned above.

Extraction and purification. Two procedures were used depending on purposes. For GC and GC/MS analyses of the mite extracts, two females or males as a group were transfered into a conical bottomed tube ( $8 \mathrm{~mm}$ in length $\times 30 \mathrm{~mm}$ in diameter, handmade), and hexane $(4 \mu \mathrm{l})$ was then added. After three minutes, the entire hexane extract in the tube was 
collected using a micro-syringe (10 $\mu \mathrm{l}$, Hamilton Co. Ltd) and subjected to a GC or GC/MS analysis.

The following procedures were used to identify the alarm pheromone component in the extract. Mites consisting of all developmental stages were separated from the stock culture by a saline flotation method (Matsumoto, 1965). The separated mites $(2.36 \mathrm{~g})$ were then dipped into hexane $(3 \mathrm{ml})$ for $3 \mathrm{~min}$, and the hexane extract was collected by filtration. The extract was applied to a $\mathrm{SiO}_{2}$ column $(250 \mathrm{mg}$, Wako-gel C-200) and eluted successively with $3 \mathrm{ml}$ each of the following solvent: hexane, ether and hexane mixture $(1 \%$ ether in hexane, 5\%,10\%, 20\% and 50\%), and ether. One aliquot of each fraction was then subjected to a GC/MS analysis. Concentration of all fractions was adjusted to 3 female equivalent per $1 \mu \mathrm{l}$, and each fraction was subjected to the bioassay.

Quantitative determination of neryl formate. A group of ten males or five females was dipped into hexane $(2 \mu \mathrm{l})$ containing octadecane as the internal standard $(0.1 \mathrm{ng} / \mu \mathrm{l})$ for three minutes in a conical-bottomed tube. The extract was subsequently analyzed by GC with FID to determine the content of active compound(s), using the following equation; $\mathrm{Y}$ (ng of neryl formate $)=0.257 \times($ peak area of neryl formate/that of octadecane $)-0.0048, \mathrm{R}^{2}=0.999$.

Method to observe time-course recovery of each component after artificial discharge of the gland contents. A part of mites in the stock culture was transferred to a new Petri dish with food, and the dish was shaken by hand to make the mites discharge all components stored in the opisthonotal glands. After ventilation for $15 \mathrm{~min}$, five females as a group were sampled and the hexane extract prepared as mentioned above was subjected to GC analyses. The contents of each component were determined and compared by sampling at each of the following time sequences; 6, 12, 18, 24, 36, 48, 60, 72, 96, 120, 144 and 168 hours later. The experiment was repeated three times and reproducibility was confirmed.

Synthesis. Neryl formate was synthesized by procedure described by Kuwahara et al., (1980b), starting from nerol (3,7-dimethyl-(Z)-2,6-octadien-1-ol) and acetic-formic anhydride in pyridine. ${ }^{1} \mathrm{H}$ NMR spectral data are as follows: $\delta 1.60(3 \mathrm{H}, \mathrm{s}), 1.68(3 \mathrm{H}, \mathrm{s}), 1.78(3 \mathrm{H}, \mathrm{s})$, $2.0 \sim 2.2(4 \mathrm{H}, \mathrm{br}), 4.65(2 \mathrm{H}, \mathrm{d}), 5.10(1 \mathrm{H}, \mathrm{br}, \mathrm{s}), 5.38(1 \mathrm{H}, \mathrm{t})$ and $8.08(1 \mathrm{H}, \mathrm{s})$.

Statistical analysis. Data obtained by the bioassay were analyzed by Mann-Whitney U test, or Kruskal-Wallis test followed by Dunn's multiple-comparison test.

\section{RESULTS}

Identification of the alarm pheromone. When a piece of filter paper impregnated with three female equivalent of the extract was introduced to the vicinity of a test mite, all the tested mites started to move and consequently went out of the circle. It took $24.1 \pm 2.3$ seconds on average for the mite to escape from the circle. On the other hand, it took $45.4 \pm 4.6$ seconds on average in the case of the solvent control. This difference was statistically significant (Mann-Whitney $U$ test, $p<0.01$ ). The fact indicated that some compound(s) present in the extract was responsible for such mite behavior, and we thought that it could be a new criterion of behavior to evaluate alarm pheromone activity statistically.

The GC/MS profile of the crude hexane extract was composed of the following eleven compounds; neral ( $\left.t_{R} 9.46 \mathrm{~min}\right)$, isopiperitenone $\left(t_{R} 9.93 \mathrm{~min}\right)$, neryl formate $\left(t_{R} 10.00 \mathrm{~min}\right)$, $\gamma$-acaridial (3-hydroxybenzene-1,2-dicarbaldehyde, $\left.t_{R} 10.17 \mathrm{~min}\right)$, tridecane $\left(t_{R} 10.24 \mathrm{~min}\right.$ ), 
isorobinal (4-isopropenyl-3-oxo-1-cyclohexene-1-carboxyaldehyde, $t_{R} 10.94 \mathrm{~min}$ ), robinal (3-oxo-4-isopropylidene-1-cyclohexene-1-carboxyaldehyde, $t_{\mathrm{R}} 12.00 \mathrm{~min}$ ), pentadecadienes, pentadecenes (apparent mixtures around $t_{R} 12.60 \mathrm{~min}$ ), pentadecane $\left(t_{R} 12.81 \mathrm{~min}\right)$, hexyl linolate $\left(t_{R} 22.87 \mathrm{~min}\right)$. All components were identified by comparison of their $G C t_{R} s$ and mass spectra with those of synthetic compounds or known components from mites as listed in Table 1. Although $\mathrm{GC} \mathrm{t}_{\mathrm{R}} \mathrm{S}$ of the following compounds; pentadecadiene, pentadecenes and hexyl linolate were identical to those of compounds present in Tyrophagus putrescentiae, positions and geometries of their doube bonds were not determined. The males contained these eleven compounds in the following decreasing order determined by total ion chromatogram of GC/MS analysis; pentadecenes, neral, $\gamma$-acaridial, hexyl linolate, tridecane, isorobinal, neryl formate, isopeperitenone, robinal, pentadecane and pentadecadiene. On the other hand, in the case of females indicated the following order; pentadecenes, isopeperitenone, neryl formate, tridecane, hexyl linolate, $\gamma$-acaridial, isorobinal, pentadecane, robinal, pentadecadiene and neral. Sexual dimorphism was observed. Males contained neral and $\gamma$-acaridial as major components, while isopiperitenone, neryl formate and tridecane were more localized in females than in males. Other six compounds were distributed equally in both sexes.

In order to determine the compound responsible for the pheromone activity, the hexane extract prepared from mite bodies $(2.36 \mathrm{~g})$ of all developmental stages was separated by

Table 1. GC/MS data for compounds obtained from the hexane extract of Tyroburus lini, GC retention times, molecular and diagnostic ions and relative abundance.

\begin{tabular}{|c|c|c|c|c|c|}
\hline \multirow[t]{2}{*}{ Compounds } & \multirow[t]{2}{*}{$\begin{array}{r}\mathrm{GC} \text { tR } \\
(\mathrm{min})\end{array}$} & \multicolumn{2}{|c|}{$\begin{array}{l}\text { Relative } \\
\text { abundance } \\
\left(\% \%^{\mathrm{a}}\right)\end{array}$} & \multirow[t]{2}{*}{$\begin{array}{l}\text { Molecular and diagnostic ions } \\
\mathrm{m} / \mathrm{z} \text { (intensity \%) }\end{array}$} & \multirow[t]{2}{*}{ Reference cited } \\
\hline & & Femal & Male & & \\
\hline Neral & 9.46 & 0.8 & 15.4 & $\begin{array}{l}41(100), 53(13), 59(16), 69(85), 84(31), 94(41) \\
109(27), 119(18), 134(10), 137(9), 152\left(\mathrm{M}^{+}, 3\right)\end{array}$ & Kuwahara et al., 1980a \\
\hline Isopiperitenone & 9.93 & 17.7 & 5.2 & $\begin{array}{l}54(12), 67(3), 82(100), 107(6), 122(5), 135(29) \\
150\left(\mathrm{M}^{+}, 25\right)\end{array}$ & Kuwahara et al., 1987 \\
\hline Neryl formate & 10.00 & 13.4 & 5.5 & $\begin{array}{l}41(52), 53(9), 69(100), 80(11), 93(43), 107(7), \\
121(22), 136(41), 182\left(\mathrm{M}^{+}, 1\right)\end{array}$ & Kuwahara et al., 1979 \\
\hline$\gamma$-Acaridial & 10.17 & 7.2 & 14.8 & $\begin{array}{l}\text { 65(18), 76(5), 93(29), 108(9), 121(100), 122(54), } \\
150\left(\mathrm{M}^{+}, 84\right)\end{array}$ & Sakata et al., 2001 \\
\hline Tridecane & 10.24 & 10.8 & 9.3 & $\begin{array}{l}\text { 43(40), 57(100), 71(70), 85(49), 99(13), 113(9), } \\
127(10), 141(7), 155(4), 184\left(\mathrm{M}^{+}, 6\right)\end{array}$ & Howard et al., 1988 \\
\hline Isorobinal & 10.94 & 6.1 & 8.0 & $\begin{array}{l}41(10), 53(14), 68(100), 79(15), 91(15), 96(55), \\
107(22), 121(13), 135(33), 149(84), 164\left(\mathrm{M}^{+}, 69\right)\end{array}$ & Sakata et al., 1996 \\
\hline Robinal & 12.00 & 2.5 & 2.1 & $\begin{array}{l}41(10), 53(7), 67(12), 77(16), 91(24), 95(20), \\
107(27), 121(21), 135(12), 149(5), 164\left(\mathrm{M}^{+}, 100\right)\end{array}$ & Leal et al., 1990 \\
\hline Pentadecadiene & 12.54 & 2.4 & 1.9 & $\begin{array}{l}41(43), 55(42), 67(100), 81(95), 95(61), 110(44), \\
124(13), 138(10), 151(5), 208\left(\mathrm{M}^{+}, 48\right)\end{array}$ & Howard et al., 1988 \\
\hline Pentadecenes & 12.60 & 24.6 & 23.9 & $\begin{array}{l}43(47), 55(83), 69(100), 83(97), 97(89), 111(50) \\
125(23), 140(7), 210\left(\mathrm{M}^{+}, 45\right)\end{array}$ & Howard et al., 1988 \\
\hline Pentadecane & 12.81 & 4.2 & 3.4 & $\begin{array}{l}41(34), 43(69), 57(100), 71(66), 85(45), 99(10) \\
113(8), 127(5), 212\left(\mathrm{M}^{+}, 12\right)\end{array}$ & Howard et al., 1988 \\
\hline Hexyl linolate & 22.87 & 10.3 & 10.5 & $\begin{array}{l}\text { 43(100), 55(70), 67(90), 81(89), 95(75), 109(49), } \\
123(34), 135(28), 149(28), 164(26), 178(23), \\
220(17), 262(53), 279(22), 364\left(\mathrm{M}^{+}, 25\right)\end{array}$ & Kuwahara et al., 1988 \\
\hline
\end{tabular}

\footnotetext{
a $\%$ of total ion detected by GC/MS
} 
$\mathrm{SiO}_{2}$ column into seven fractions and subsequently subjected to bioassay. The fraction eluted with $1 \%$ ether in hexane indicated the alarm pheromone activity at a dose equivalent to three females and contained neryl formate as the major components by GC/MS analyses, whereas all the other fractions were inactive at the same doses as summarized in Fig. 1. A mixture of hydrocarbons was recovered in the hexane eluate, likewise, a mixture of neral and robinal in a 5\% fraction, isopiperitenone in a 10\% fraction, and isorobinal in $10 \%$ and $20 \%$ fractions. 3-Hydroxybenzene-1,2-dicarbaldehyde was not recovered in any fraction, as mentioned in the previous study (Sakata et al., 2001). As a result, neryl formate was concluded to be the active principle of the pheromone.

Biological activity of synthetic neryl formate. The dose-response relationship of synthetic neryl formate is summarized in Fig. 2. The observed times at each dose (sec/ng) (each $\mathrm{n}=20$ ) were as follows: $40.6 \pm 4.1 / 0.01 \mathrm{ng} ; 21.1 \pm 1.4 ; 0.1 / 0.05 \mathrm{ng} ; 21.8 \pm 1.2 / 0.1 \mathrm{ng} ; 24.1 \pm 1.7 /$ $1 \mathrm{ng} ; 28.9 \pm 2.7 / 10 \mathrm{ng}$. The time values at $0.05 \mathrm{ng}, 0.1 \mathrm{ng}$ and $1 \mathrm{ng}$ doses were all significant to the control (Kruskal-Wallis test followed by Dunn's multiple-comparison test, $\mathrm{p}<0.01$ ),

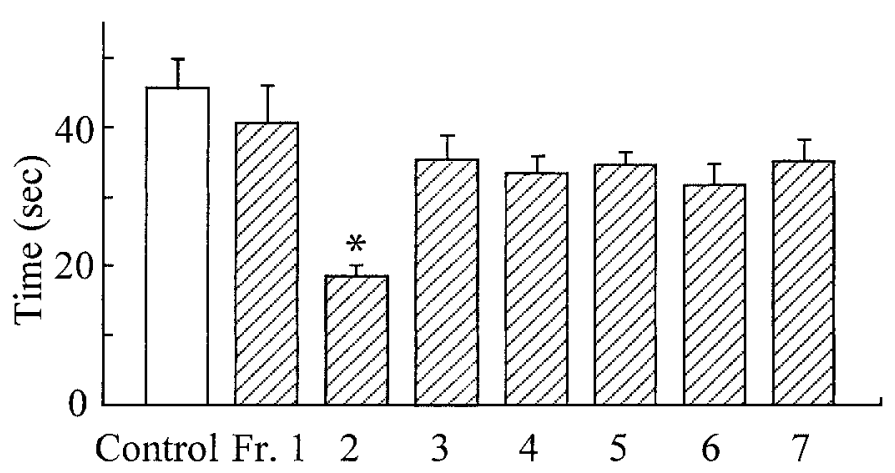

Fig. 1. Alarm pheromone activities of $\mathrm{SiO}_{2}$ column eluates.

*; Significant differences $(\mathrm{p}<0.01)$ determined by Kruskal-Wallis test followed by Dunn's multiple-comparison test relative to the control.

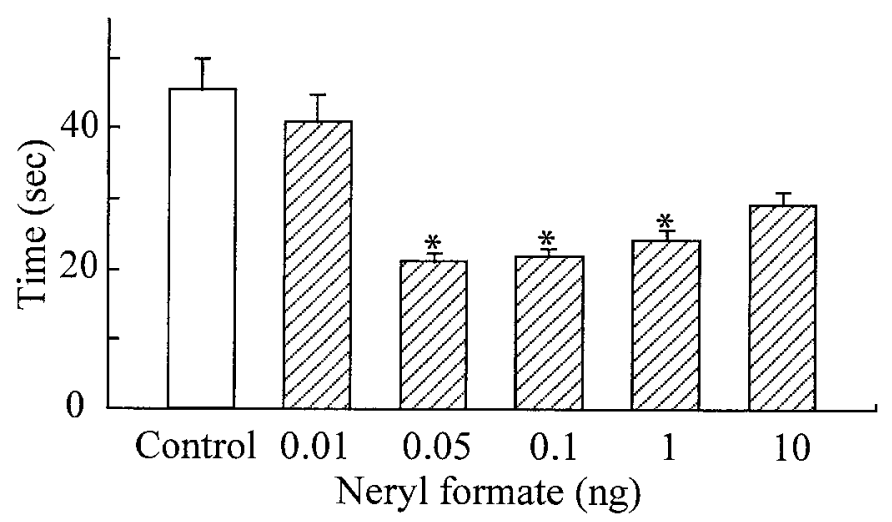

Fig. 2. Dose-response relationships of synthetic neryl formate. *; Significant differences $(\mathrm{p}<0.01)$ determined by Kruskal-Wallis test followed by Dunn's multiple-comparison test relative to the control. 


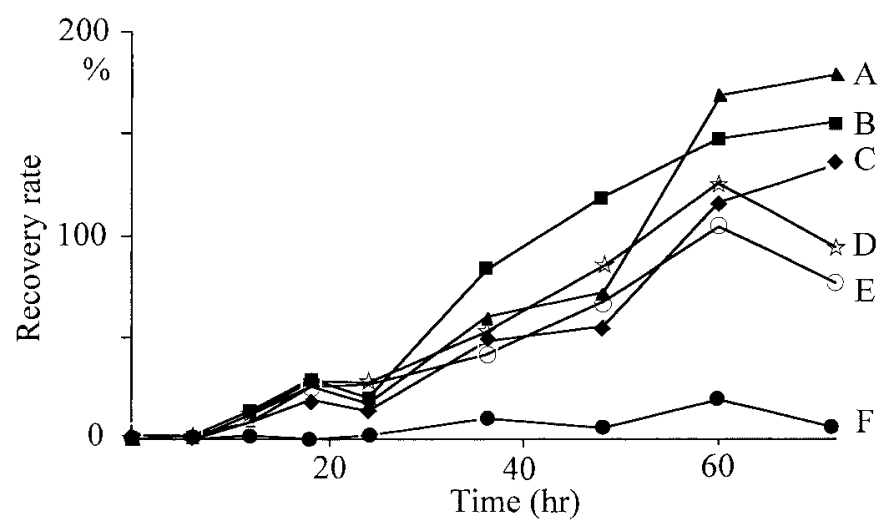

Fig. 3. Time course recoveries of six representative components present in the opisthonotal gland.

A: $\gamma$-Acaridial, B: mixture of pentadecenes, C: isopiperitenone, D: robinal, $\mathrm{E}$ : isorobinal and $\mathrm{F}$ : neryl foramte (the alarm pheromone).

indicating the alarm pheromone activity of the compound.

Quantitative determination of neryl formate in mites. The male extract obtained from 10 mites was calculated to contain $0.80 \pm 0.06 \mathrm{ng}$ (on average, $\mathrm{n}=20$ ) of neryl formate, while 5 females extract $0.805 \pm 0.085 \mathrm{ng}$ (on average, $\mathrm{n}=20$ ).

Time-course recovery of each component after artificial discharge of the gland contents. Apparently no GC responses of eleven compounds were obtained from the extract of five females, when the extract was prepared from mites just after being shaken and ventilated for $15 \mathrm{~min}$. GC peaks of each component appeared to be restored along with time elapsed after disturbance. Recovery rates of all components except neryl formate seemed to be the same and reached to each original level within 60 hours, whereas neryl formate did not recover even after 72 hours ( $20 \%$ at the best) as demonstrated typically in Fig. 3. It took 7 days to reach the original level (data not shown).

\section{DISCUSSION}

This is the first example of Tyroborus mite possessing an alarm pheromone. Neryl formate [3,7-dimethyl-(Z)-2,6-octadienyl formate] was identified as the active principle of $T$. lini. The female contained the compound (ca. $0.16 \mathrm{ng}$ per each) twice the amonunt of the male (ca. $0.08 \mathrm{ng}$ per each). The synthesized preparation of neryl formate demonstrated the activity at $0.05-1 \mathrm{ng}$ dose, which corresponded to $0.3-6.2$ female equivalent and to $0.6-12$ male equivalent. These results indicate that the alarm pheromone activity might be manifested only after a total discharge of a mite content at a time, like the cases of $R$. robini (Mizoguchi et al., 2003) and Schwiebea elongata (Nishimura et al., 2002).

Neryl formate is one of the most commonly distributed components among astigmatid mites and is detected in 17 species among 52 species examined (Kuwahara, 1999). Its alarm pheromone function has at first been demonstrated in Tyrophagus putrescentiae (Kuwahara et al., 1975), and then among four species of Rhizoglyphus (R. robini, R. setosus, and two Rhizoglyphus spp.) (Kuwahara et al., 1988a: Akiyama et al., 1997). This is the sixth 
example, where neryl formate functions as the alarm pheromone. The biological roles of neryl formate for the other 11 species were obscure at present.

In the present study, the alarm pheromone activity was evaluated quantitatively for the first time, representing mite's escaping behavior as a time-span required to move a fixed length. The apparent linear speed under influence of the alarm pheromone was calculated to be $12 \mathrm{~mm} / \mathrm{min}$, while the normal speed of locomotion was $5.9 \mathrm{~mm} / \mathrm{min}$. It means that the average linear speed upon exposure of the hexane extract becomes twice as faster than the control (Mann-Whitney $U$ test, $\mathrm{p}<0.01$ ). The alarm pheromone appeared to accelerate straight-forward movement, while at the normal state mite repeatedly turns with seemingly the same speed and takes time to move out from the set circle. Because the method is simple and versatile for statistical evaluation of the alarm pheromone activity, it might be used hereafter as one of a standard method for alarm pheromone study.

All of compounds from Astigmata are believed to be products of the opisthonotal glands, as evidenced in Rhyzoglyphus robini (Mizoguchi et al., 2003). The mites actually discharge all gland contents upon disturbance by shaking (Kuwahara et al., 1979, 1980b). In the present study, the refilling feature after discharge was firstly determined for all components to the original level of storage. The result indicated that all compounds except the alarm pheromone were restored within 60 hours, whereas the pheromone only reached to $20 \%$ of the original level of quantity even at 72 hours after total discharge. It took seven days for the alarm pheromone neryl formate to reach the original level. This fact implies that neryl formate production may take higher cost than the other compounds in the glands. Astigmata is relatively slow locomotor and weak to escape from predators, and therefore, it is natural to suppose that the pheromone is used frequently and may be restored quickly. The fact was, however, totally unexpected. This is the first report referring to the time-course to refill the gland's reservoir. At present none of reasonable explanation is available for its slow recovery, and similar experiments should be carried out for other species possessing the alarm pheromone.

Hexyl linolate has been known as one of the components characteristic only to the genus Tyrophagus and its occurrence has been strictly restricted among species of the genus (Kuwahara et al., 1988b, 1991 \& 1999), whereas this unususal wax component has also been detected in T. lini as one of the major components. As mentioned, the species have once been grouped into the genus Tyrophagus. From a chemotaxonomy viewpoint, it might be correct to identify the present species as a member of the genus Tyrophagus.

\section{REFERENCES}

Akiyama, M., T. Sakata, N. Mori, T. Kato, H. Amano and Y. Kuwahara (1997): Chemical ecology of astigmatid mites. XLVI. Neryl formate, the alarm pheromone of Rhizoglyphus setosus Manson (Acarina: Acaridae) and the common pheromone component among four Rhizoglyphus mites. Appl. Entomol. Zool., 32: 75-79.

Brady, J. (1970): The mites of poultry litter. Observations on the bionomics of common species, with a species list for England and Wales. J. Appl. Ecol., 7: 331-348.

Howard, R. W., Y. Kuwahara, H. Suzuki and T. Suzuki (1988): Pheromone study on acarid mites. XII. Characterization of the hydrocarbons and external gland morphology of the opisthonotal glands of six species of mites (Acari: Astigmata). Appl. Entomol. Zool., 23: 58-66.

Kuwahara, Y. (1991): Pheromone studies on astigmatid mites-alarm, aggregation and sex. In: Modern Acarology (eds., 
Dusbabek, F. and Bukva, V.), Vol. 1, pp. 43-52, SPB Academic Publishing bv, The Hague and Academia, Prague.

Kuwahara, Y. (1999): Chemical ecology in astigmatid mites. In: Environmental entomology: behavior, physilogy and chemical ecology (eds., Hidaka, T., Matsumoto, Y. and Honda, K.), pp. 380-393, University of Tokyo Press, Tokyo. (In Japanese)

Kuwahara, Y., K. Akimoto, W. S. Leal, H. Nakao and T. Suzuki (1987): Isopiperitenone: a new alarm pheromone of the acarid mite, Tyrophagus similis (Acarina, Acaridae). Agric. Biol. Chem., 51: 3441-3442.

Kuwahara, Y., H. Fukami, S. Ishii, K. Matsumoto and Y. Wada (1979): Pheromone study on acarid mites II. Presence of the alarm pheromone in the mold mite, Tyrophagus putrescentiae (Schrank) (Acarina: Acaridae) and the site of its production. Jap. J. Sanit. Zool., 30: 309-314.

Kuwahara, Y., H. Fukami, S. Ishii, K. Matsumoto and Y. Wada (1980a): Pheromone study on acarid mite III. Citral: isolation and identification from four species of acarid mite, and its possible role. Jap. J. Sanit. Zool., 31: 49-52.

Kuwahara, Y., S. Ishii and H. Fukami (1975): Neryl formate: Alarm pheromone of the cheese mite, Tyrophagus putrescentiae (Schrank) (Acarina, Acaridae). Experientia, 31: 1115-1116.

Kuwahara, Y., W. S. Leal, K. Akimoto, Y. Nakano and T. Suzuki (1988b): Pheromone study on acarid mites XVI. Identification of hexyl linolate in acarid mites and its distribution among the genus Tyrophagus. Appl. Entomol. Zool., 23: 338-344.

Kuwahara, Y., W. S. Leal, Y. Nakono, Y. Kaneko, H. Nakao and T. Suzuki (1989): Pheromone study on astigmatid mites XXIII. Identification of the alarm pheromone on the acarid mite, Tyrophagus neiswanderi and species specificities of alarm pheromones among four species of the same genus. Appl. Entomol. Zool., 24: 424-429.

Kuwahara, Y., K. Matsumoto and Y. Wada (1980b): Pheromone study on acarid mites IV. Citral: composition and function as an alarm pheromone and its secretory gland in four species of acarid mites. Jap. J. Sanit. Zool., 31: 73-80.

Kuwahara, Y., C. Shibata, K. Akimoto, M. Kuwahara and T. Suzuki (1988a): Pheromone study on acarid mites. XIII. Identification of neryl formate as an alarm pheromone from the bulb mite, Rhizoglyphus robini (Acarina: Acaridae). Appl. Entomol. Zool., 23: 76-80.

Leal, W. S., Y. Kuwahara and T. Suzuki (1990): Robinal, a highly conjugated monoterpenoid from the mite, Rhizoglyphus robini. Chemical ecology of astigmatid mites, XXVII. Naturwissenschaften, 77: 387-388.

Leal, W. S., Y. Nakano, Y. Kuwahara, H. Nakao and T. Suzuki (1988b): Pheromone study on acarid mites XVII. Identification of 2-hydroxy-6-methyl-benzaldehyde as the alarm pheromone of the acarid mite, Tyrophagus perniciosus (Acarina: Acaridae), and its distribution among related mites. Appl. Entomol. Zool., 23: 422-427.

Nishimura, K., N. Shimizu, N. Mori and Y. Kuwahara (2002): Chemical ecology of astigmatid mites LXIV. The alarm pheromone neral functions as an attractant in Schwiebea elongata (Banks) (Acari: Acaridae). Appl. Entomol. Zool., 37: 13-18.

Matsumoto, K. (1965): Studies on the environmental factors for the breeding of grain mites VI. Digestive enzymes of the grain mites Carpoglyphus lactis, Aleuroglyphus ovatus and Tyrophagus dimidiatus. Jap. J. Sanit. Zool., 16: 86-89.

Mizoguchi, A., N. Mori, R. Nishida and Y. Kuwahara (2003): $\alpha$-Acaridial as the female sex pheromone from an alarm pheromone emitting mite Rhizoglyphus robini. Chemical ecology of astigmatid mites LXVIII. J. Chem. Ecol., in press.

Nakao, H. (1991): Studies on acarid mites (Acari: Astigmata) damaging vegetable plants: II. Damage to vegetable seedlings. Jpn. J. Appl. Entomol. Zool., 35: 303-310. (in Japanese with English summary)

Nakao, H. and K. Kurosa (1988): Description of four species of acarid mites newly recorded from Japan, with reference to the damage caused to crops (Acari: Astigmata). Jpn. J. Appl. Entomol. Zool., 32: 135-142. (in Japanese with English summary)

Noguchi, S., N. Mori, K. Kurosa and Y. Kuwahara (1998): Chemical ecology of astigmatid mites XLIX. $\beta$-Acaridial (2(E)-(4-Methyl-3-pentenylidene)-butanedial), the alarm pheromone of Tyrophagus longior Gervais (Acarina: Acaridae). Appl. Entomol. Zool., 33: 53-57.

Sakata, T. and Y. Kuwahara (2001): Structure elucidation and synthesis of 3-hydroxybenzene-1,2-dicarbaldehyde from astigmatid mites. Biosci. Biotech. Biochem., 65: 2315-2317.

Sakata, T., Y. Kuwahara and K. Kurosa (1996): 4-Isopropenyl-3-oxo-1-carboxyaldehyde, isorobinal: A novel monoterpen from the mite Rhizoglyphus sp. (Astigmata: Rhizoglyphinae). Naturwissenschaften, 83: 427. 
摘要

無気門亜目コナダニ Tyroborus lini Oudemans の警報フェロモンの同定 冨田章裕, 清水 伸泰, 森 直樹, 西田律夫, 桑原保正 (京大院農), 中尾弘志 (北海道立中央農業試験場)

無気門亜目コナダニ Tyroborus lini Oudemans のヘキサン抽出物中に警報フェロモン活性を 認め, その活性化合物を GC/MS および GC による分析から蟻酸ネリル (Z)-3,7-dimethyl-2,6octadienyl formate と同定した. 合成した蟻酸ネリルは，0.05-1 ng で活性を示した。同活性化 合物の雌雄の含有量は, それぞれ平均 0.16 および $0.08 \mathrm{ng}$ であった. 警報フェロモンが分泌 腺から完全に放出されてから元のレベルに戻るには 7 日要したが, 分泌腺中の他の成分は 60 時間であった. 